\title{
PENGARUH KONSELING GIZI TERHADAP PENGETAHUAN, SIKAP, PRAKTIK IBU DALAM PEMBERIAN MAKAN ANAK, DAN ASUPAN ZAT GIZI ANAK STUNTING USIA 1-2 TAHUN DI KECAMATAN SEMARANG TIMUR
}

\author{
Tiara Rosania Hestuningtyas, Etika Ratna Noer ${ }^{*}$ \\ Program Studi Ilmu Gizi Fakultas Kedokteran Universitas Diponegoro \\ J1.Dr.Sutomo No.18, Semarang, Telp (024) 8453708, Email : gizifk@ undip.ac.id
}

\begin{abstract}
Backgorund: Stunting is a short stature caused by chronic malnutrition. Nutrient intake is one of the factors that directly influence to stunting. Nutrient intake is influenced by mother's behavior. Nutrition counseling is one way to improve mother's behavior, including knowledge, attitude, and practice so that the nutrient intake can be improved. Objective: To identify the influence of nutrition counseling to mother's knowledge, attitude, practice in children feeding, and nutrient intake of stunted children among 1-2 years.

Methods: An experimental study with quasi experiment nonequivalent control group design on stunted children among 1-2 years in East Semarang District. Samples were 20 mothers in control group and 20 mothers in treatment group. Control group were stunted children whose mothers were not given nutrition counseling. Treatment group were stunted children whose mothers were given nutrition counseling. Counseling was done one time per week for 6 weeks. Subjects were mothers who had stunted children. Data were analyzed by dependent t test or independent $t$ test for normally distributed data, and wilcoxon or mann-whitney for not normally distributed data.

Results: Subjects consisted of 65\% girls, and $85 \%$ of subjects were not exclusively breastfed. Mother's education was $60 \%$ high school, 57,5\% of respondents were housewives, and respondent's household income was $60 \%$ $<$ Semarang City Minimum Wage. The mother's attitude and practice, and child's nutrient intake scores in the control group had not increased significantly, but mother's knowledge scores increased significantly $(p=0.022)$. In the treatment group, there was an increased in mother's knowledge scores, attitude, and practice, and child's nutrient intake significantly ( $p=0.000)$. There were different in changes of mother's knowledge, attitude, practice, and child's nutrient intake significantly (0.000) between the treatment group and the control group.

Conclusion: Nutrition counseling can improve mother's knowledge, attitude, practice in children feeding, and child's nutrient intake significantly.
\end{abstract}

Keywords: Mother's knowledge; mother's attitude; mother's practice; children feeding; child's nutrient intake; stunting

\section{ABSTRAK}

Latar Belakang: Stunting adalah postur tubuh pendek yang timbul karena malnutrisi kronis. Asupan zat gizi adalah salah satu faktor yang berpengaruh langsung terhadap stunting. Asupan zat gizi dipengaruhi oleh perilaku ibu. Konseling gizi merupakan salah satu cara memperbaiki perilaku ibu, meliputi pengetahuan, sikap, dan praktik ibu sehingga asupan zat gizi dapat diperbaiki.

Tujuan: Menganalisis pengaruh konseling gizi terhadap pengetahuan, sikap, praktik ibu dalam pemberian makan anak, dan asupan zat gizi anak stunting usia 1-2 tahun.

Metode: Penelitian eksperimen dengan quasi experiment nonequivalent control group design pada anak stunting usia 1-2 tahun di Kecamatan Semarang Timur. Jumlah sampel adalah 20 ibu pada kelompok kontrol dan 20 ibu pada kelompok perlakuan. Kelompok kontrol adalah ibu dari anak stunting yang tidak diberi konseling gizi. Kelompok perlakuan adalah ibu dari anak stunting yang diberi konseling gizi. Konseling dilakukan 1 kali tiap minggu selama 6 minggu. Subjek penelitian adalah ibu yang mempunyai anak stunting. Analisis data menggunakan uji beda, yaitu dependent $t$ test atau independent t test untuk data yang berdistribusi normal, dan wilcoxon atau mann-whitney untuk data yang tidak berdistribusi normal.

Hasil: Sebanyak 65\% subjek adalah perempuan, dan 85\% subjek tidak mendapatkan ASI eksklusif. Pendidikan responden $60 \%$ adalah SMA, 57,5\% responden merupakan ibu rumah tangga, dan pendapatan rumah tangga responden $60 \%$ <Upah Minimum Kota Semarang. Pada kelompok kontrol, tidak terdapat peningkatan skor sikap, praktik ibu, dan asupan zat gizi anak secara signifikan, tetapi skor pengetahuan meningkat signifikan $(p=0,022)$. Pada kelompok perlakuan terdapat peningkatan skor pengetahuan, sikap, praktik ibu, dan asupan zat gizi anak secara signifikan $(p=0,000)$. Terdapat perbedaan perubahan pengetahuan sikap, praktik ibu, dan asupan zat gizi anak secara signifikan (0,000) antara kelompok perlakuan dan kelompok kontrol.

Simpulan: Konseling gizi dapat meningkatkan pengetahuan, sikap, praktik ibu dalam pemberian makan anak, dan asupan zat gizi anak secara signifikan.

Kata kunci: Pengetahuan ibu; sikap ibu; praktik ibu; pemberian makan anak; asupan zat gizi; stunting

\footnotetext{
${ }^{*}$ Penulis Penanggungjawab
} 


\section{PENDAHULUAN}

Stunting adalah postur tubuh pendek yang timbul karena malnutrisi kronis. ${ }^{1}$ Kategori stunting didasarkan pada indeks Panjang Badan menurut Umur $(\mathrm{PB} / \mathrm{U})$ atau Tinggi Badan menurut Umur (TB/U) dengan ambang batas (z-score) antara -3 SD sampai dengan $<-2$ SD. ${ }^{2}$ Berdasarkan Riset Kesehatan Dasar (Riskesdas) 2010 diketahui prevalensi stunting pada balita di Indonesia mencapai $35,7 \%{ }^{3}$ Stunting pada balita dapat merugikan perkembangan fisik, dan berpengaruh terhadap tingkat kecerdasan yang rendah. ${ }^{1}$ Anak yang mengalami stunting memiliki risiko 9 kali lebih besar untuk memiliki nilai IQ dibawah ratarata dibandingkan anak yang berstatus gizi normal. $^{4}$

Salah satu faktor yang berpengaruh secara langsung pada balita stunting adalah rendahnya asupan zat gizi terutama energi, protein, iron, zinc, dan kalsium. ${ }^{5-6}$ Asupan zat gizi tersebut diperoleh dari Air Susu Ibu (ASI) dan Makanan Pendamping-Air Susu Ibu (MP-ASI). Penelitian menunjukkan bahwa durasi menyusui dan pemberian ASI eksklusif berhubungan secara signifikan dengan status gizi anak terutama untuk $z$-score TB/U. ${ }^{7}$ Ketepatan pemberian MP-ASI juga mempunyai pengaruh yang signifikan pada peningkatan tinggi badan anak usia 6-24 bulan sehingga dapat mengurangi risiko stunting. ${ }^{8}$ Dalam upaya perbaikan status gizi, termasuk stunting, intervensi dengan satu mikronutrien saja kurang efektif. ${ }^{6}$ Oleh karena itu, untuk melengkapi asupan zat gizi anak, dapat dilakukan dengan menggunakan bahan makanan yang beragam pada MP-ASI karena keragaman makanan yang kurang merupakan prediktor kuat terjadinya stunting. ${ }^{9}$

Asupan zat gizi yang rendah dipengaruhi oleh pola asuh, salah satunya adalah perilaku pemberian makan yang tidak tepat. Penelitian menyebutkan adanya hubungan yang nyata antara pola pengasuhan dengan stunting. ${ }^{10}$ Perilaku pemberian makanan balita dipengaruhi oleh pengetahuan gizi ibu. Pengetahuan gizi ibu adalah salah satu faktor yang mempunyai pengaruh signifikan pada kejadian stunting. ${ }^{11}$ Oleh karena itu, upaya perbaikan stunting dapat dilakukan dengan peningkatan pengetahuan sehingga dapat memperbaiki perilaku pemberian makan pada anak, maka asupan makan anak juga dapat diperbaiki, yaitu dengan konseling gizi.

Konseling gizi adalah interaksi antara klien dan konselor untuk mengidentifikasi permasalahan gizi yang terjadi, dan mencari solusi untuk masalah tersebut. ${ }^{12}$ Konseling gizi dapat meningkatkan pengetahuan, sikap, dan praktik gizi, serta dapat meningkatkan skor TB/U pada anak. ${ }^{13}$

Upaya perbaikan stunting sebaiknya difokuskan pada anak usia $<2$ tahun karena kisaran usia tersebut merupakan salah satu faktor risiko terjadinya stunting. ${ }^{14}$ Berdasarkan asumsi tersebut, uji pendahuluan yang dilakukan di Kecamatan Semarang Timur ditemukan kejadian stunting paling banyak terjadi pada usia 1-2 tahun. Pada pengukuran 370 anak usia 1-2 tahun, terdapat 60 anak stunting $(16,22 \%)$ dan 25 anak severely stunting $(6,76 \%)$.

Berdasarkan uraian di atas, konseling gizi dapat berperan penting dalam upaya perbaikan stunting. Oleh karena itu, peneliti tertarik untuk mengetahui pengaruh konseling gizi terhadap pengetahuan, sikap, praktik ibu dalam pemberian makan anak, dan asupan zat gizi anak stunting usia 1-2 tahun di Kecamatan Semarang Timur. Tujuan penelitian ini adalah untuk menganalisis pengaruh konseling gizi terhadap pengetahuan, sikap, praktik ibu dalam pemberian akan anak, dan asupan zat gizi anak stunting usia 1-2 tahun.

\section{METODE PENELITIAN}

Penelitian ini dilaksanakan di Kecamatan Semarang Timur meliputi Kelurahan Bugangan, Kebon Agung, Mlatiharjo, Mlatibaru, Kemijen, Rejosari, Sarirejo, Karang Tempel, dan Karangturi pada bulan Mei-Juli 2013. Jenis penelitian eksperimen menggunakan desain penelitian quasi experiment nonequivalent control group design. Populasi dalam penelitian ini adalah seluruh ibu yang mempunyai anak stunting usia 1-2 tahun yang berada di Kota Semarang. Subjek penelitian adalah semua kelompok perlakuan dan kontrol. Kelompok perlakuan adalah ibu dari anak stunting usia 1-2 tahun dengan indeks z-skor TB/U -3 sampai <-2 SD yang diberi konseling gizi dan kelompok kontrol adalah ibu dari anak stunting usia 1-2 tahun dengan indeks z-skor TB/U -3 sampai <-2 SD yang tidak diberi konseling gizi. Kriteria inklusi penelitian ini adalah ibu yang mempunyai anak stunting usia 1-2 tahun, dan tinggal menetap di Kecamatan Semarang Timur. Kriteria eksklusi, yaitu orangtua menolak diberikan konseling, dan pindah dari Semarang Timur. Jumlah sampel yang digunakan sebanyak 20 subjek pada masing-masing kelompok yang dihitung menggunakan rumus dan telah ditambah dengan kemungkinan drop out (10\%). Pengambilan subjek dilakukan secara consecutive sampling dan dilakukan matching terhadap tingkat pendidikan ibu. 
Variabel bebas adalah konseling gizi, sedangkan variabel terikat, yaitu pengetahuan, sikap, praktik ibu dalam pemberian makan anak, dan asupan zat gizi anak stunting usia 1-2 tahun meliputi asupan energi, protein, iron, zinc, dan kalsium. Data yang dikumpulkan antara lain, karakteristik ibu dan anak, status gizi stunting, pengetahuan, sikap, praktik ibu dalam pemberian makan anak, dan asupan zat gizi anak stunting usia 1-2 tahun. Instrumen yang digunakan adalah kuesioner, formulir recall 24 jam, leaflet standar diet, leaflet daftar bahan makanan penukar, dan infantometri.

Karakteristik ibu dan anak, meliputi jenis kelamin anak, riwayat ASI eksklusif, pendidikan ibu, pekerjaan ibu, dan pendapatan keluarga ratarata per bulan. Anak mempunyai riwayat ASI eksklusif jika anak hanya menerima ASI saja, dan tidak ada cairan atau padatan lainnya, bahkan air, dengan pengecualian larutan rehidrasi oral, sirup yang mengandung vitamin, mineral, atau obatobatan. ${ }^{15}$ Pendapatan rumah tangga rata-rata per bulan merupakan pendapatan yang diterima oleh rumah tangga bersangkutan, baik yang berasal dari pendapatan kepala rumah tangga atau anggota rumah tangga setiap bulan. ${ }^{16}$ Dalam hal ini pendapatan berpedoman pada Upah Minimum Kota (UMK) Semarang. Surat Keputusan Gubernur Nomor: 561.4/58 tahun 2012 tentang Upah Minimum 35 Kabupaten/Kota di Provinsi Jawa Tengah Tahun 2013, menetapkan UMK Semarang sebesar Rp 1.209.100,00.

Konseling gizi adalah proses komunikasi dua arah antara klien dan konselor untuk mengidentifikasi permasalahan gizi yang terjadi dan bersama-sama mencari solusi untuk masalah tersebut. Konseling dilakukan setiap 1 minggu 1 kali selama 6 minggu dengan waktu 15-20 menit setiap pertemuan. Pertemuan dilakukan dengan menyesuaikan waktu luang subjek.

Status gizi stunting adalah gambaran keadaan tubuh sebagai akibat dari keadaan kurang gizi kronis yang dianalisis berdasarkan indeks $\mathrm{TB} / \mathrm{U}$ menurut baku standar antropometri WHO 2005 dengan nilai $z$-score antara -3 sampai dengan $<-2$ menggunakan software WHO Anthro 2005. Pengukuran status gizi stunting dilakukan 1 kali pada awal penelitian, sedangkan pengetahuan, sikap, praktik ibu dalam pemberian makan anak, dan asupan zat gizi anak diukur 2 kali, yaitu pada awal dan akhir penelitian.

Pengetahuan ibu adalah tingkat pemahaman ibu tentang pemberian makan pada anak usia 1-2 tahun yang diukur menggunakan kuesioner sebanyak 25 pertanyaan dengan ketentuan nilai 0 jika jawaban salah dan 1 bila benar kemudian dilakukan penjumlahan skor dibagi jumlah pertanyaan dikali 100\%. Subjek dikategorikan berpengetahuan kurang bila jawaban benar $<60 \%$, berpengetahuan cukup jika jawaban benar $60-80 \%$, dan berpengetahuan baik jika jawaban benar $>80 \%$. Sikap ibu adalah kesiapan ibu untuk bertindak tentang pemberian makanan pada anak yang diukur dengan kuesioner sebanyak 20 pertanyaan dengan 4 skala kategori jawaban. Pertanyaan dalam bentuk positif dan negatif dengan skor bertingkat, yaitu $4,3,2$, dan 1 kemudian dilakukan penjumlahan skor. Total skor selanjutnya dibandingkan dengan mean skor kelompok dan dinyatakan dalam satuan deviasi standar kelompok untuk mengubah skor individual menjadi skor standar menggunakan rumus skor $\mathrm{T}$ sebagai berikut: ${ }^{17}$

$\mathrm{T}=50+10\left[\frac{\mathrm{X}-\ddot{\mathrm{X}}}{\mathrm{s}}\right]$

Subjek mempunyai sikap baik jika skor $\mathrm{T}$ $>60 \%$ dari skor tertinggi, yaitu 80, dan sikap kurang jika skor $\mathrm{T}<60 \%$ skor tertinggi. Praktik ibu dalam pemberian makan anak adalah kegiatan ibu yang berhubungan dengan pemberian makan anak usia 1-2 tahun yang dapat diketahui melalui kuesioner sebanyak 15 pertanyaan dengan ketentuan memiliki skor 1 jika jawaban benar dan skor 0 jika jawaban salah kemudian dilakukan penjumlahan skor dibagi jumlah pertanyaan dikali $100 \%$. Subjek dikategorikan kurang bila jawaban benar $\leq 60 \%$, dan baik jika jawaban benar $>60 \%$.

Asupan zat gizi adalah jumlah zat gizi, meliputi energi, protein, iron, zinc, dan kalsium yang berasal dari asupan makanan anak dalam sehari. Pencatatan asupan makan anak dilakukan selama 3 hari tidak berturut-turut menggunakan formulir recall 24 jam dalam ukuran rumah tangga (URT) dan dikonversi ke dalam satuan gram. Perhitungan asupan zat gizi sehari menggunakan Nutrisoft. Rata-rata asupan zat gizi dihitung berdasarkan total asupan zat gizi dalam 3 hari dibagi 3. Asupan zat gizi dikategorikan defisit apabila asupan $<70 \%$ dari RDA (Recommended Dietary Allowances), asupan kurang apabila berkisar 70-80\% dari RDA, asupan sedang jika berkisar $80-99 \%$ dari RDA, dan baik apabila $\geq 100 \%$ dari RDA. ${ }^{18}$

Perbedaan pengetahuan, sikap, praktik ibu dalam pemberian makan anak, dan asupan zat gizi anak dianalisa menggunakan uji beda. Data dengan sebaran yang normal $(\mathrm{p}>0,05)$ diuji dengan dependent $t$ test dan independent $t$ test, sedangkan 
data dengan sebaran yang tidak normal $(\mathrm{p}<0,05)$ diuji dengan uji Wilcoxon dan Mann-whitney.

\section{HASIL PENELITIAN}

\section{Karakteristik Subjek dan responden}

Subjek dalam penelitian ini berjumlah 40 ibu, yang terdiri atas 20 ibu pada kelompok kontrol dan 20 ibu pada kelompok perlakuan. Jenis kelamin anak sebagian besar perempuan (65\%). Zskor TB/U mempunyai nilai median $-2,44$ dengan nilai minimum $-2,99$ dan nilai maximum $-2,10$.
Hasil penelitian juga membuktikan bahwa sebagian besar ibu mempunyai riwayat tidak memberikan ASI eksklusif.

Dalam penelitian ini, stunting pada anak sebagian besar terjadi pada ibu-ibu dengan pendidikan tinggi, yaitu SMA dan bekerja sebagai ibu rumah tangga. Pendapatan rumah tangga ratarata per bulan sebagian besar di bawah Upah Minimum Kota (UMK) Semarang. Distribusi karakteristik ibu dan anak selengkapnya terdapat pada Tabel 1.

Tabel 1. Distribusi frekuensi jenis kelamin anak, riwayat ASI eksklusif, tingkat pendidikan ibu, pekerjaan $\mathrm{ibu}$, dan pendapatan rumah tangga rata-rata per bulan

\begin{tabular}{|c|c|c|}
\hline Variabel & $\mathrm{N}$ & $\%$ \\
\hline $\begin{array}{l}\text { 1. Jenis kelamin anak } \\
\text { - Laki-laki } \\
\text { - Perempuan }\end{array}$ & $\begin{array}{l}14 \\
26\end{array}$ & $\begin{array}{l}35 \\
65\end{array}$ \\
\hline $\begin{array}{l}\text { 2. Riwayat ASI eksklusif } \\
\text { - Eksklusif ( } \leq 6 \text { bulan) } \\
\text { - Tidak eksklusif }(>6 \text { bulan) }\end{array}$ & $\begin{array}{c}6 \\
34\end{array}$ & $\begin{array}{l}15 \\
85\end{array}$ \\
\hline $\begin{array}{l}\text { 3. Tingkat pendidikan ibu } \\
\text { - SD/sederajat } \\
\text { - SMP/sederajat } \\
\text { - SMA/sederajat } \\
\text { - Perguruan Tinggi/akademi }\end{array}$ & $\begin{array}{c}4 \\
8 \\
24 \\
4 \\
\end{array}$ & $\begin{array}{l}10 \\
20 \\
60 \\
10 \\
\end{array}$ \\
\hline $\begin{array}{l}\text { 4. Pekerjaan Ibu } \\
\text { - Ibu Rumah Tangga } \\
\text { - Pegawai swasta } \\
\text { - Wiraswasta } \\
\text { - Lainnya }\end{array}$ & $\begin{array}{c}23 \\
9 \\
7 \\
1\end{array}$ & $\begin{array}{c}57,5 \\
22,5 \\
17,5 \\
2,5\end{array}$ \\
\hline $\begin{array}{l}\text { 5. Pendapatan rumah tangga rata-rata per } \\
\text { bulan } \\
-<\quad \text { Upah Minimum Kota } \\
\text { (UMK) } \\
-\geq \quad \text { Upah Minimum Kota (UMK) }\end{array}$ & $\begin{array}{l}24 \\
16\end{array}$ & $\begin{array}{l}60 \\
40\end{array}$ \\
\hline
\end{tabular}

Gambaran pengetahuan, sikap, praktik ibu dalam pemberian makan anak, dan asupan zat gizi anak pada kelompok kontrol dan perlakuan pada awal penelitian

Sebagian besar responden pada kelompok kontrol maupun perlakuan, berpengetahuan cukup, dan mempunyai sikap baik pada awal penelitian. Namun, praktik ibu dalam pemberian makan anak sebagian besar kurang, sedangkan pada kelompok perlakuan, kategori kurang dan baik memiliki proporsi yang sama. Asupan energi pada kelompok kontrol maupun perlakuan sebagian besar tergolong defisit. Berbeda halnya dengan protein yang sebagian besar berkategori baik. Asupan iron pada kelompok kontrol, sebagian besar baik, sedangkan kelompok perlakuan sebagian besar defisit. Asupan zinc sebagian besar baik pada kelompok kontrol maupun perlakuan. Asupan kalsium sebagian besar baik pada kelompok kontrol, sedangkan pada kelompok perlakuan sebagian besar defisit. Selengkapnya, terdapat pada Tabel 2.

Dalam menggambarkan kesetaraan karakteristik pada kelompok kontrol dan perlakuan pada awal penelitian, ditunjukkan dengan hasil uji statistik, yaitu tidak ada perbedaan yang signifikan ( $p>0,05$ ) antara kelompok kontrol dan perlakuan baik pengetahuan, sikap, praktik ibu dalam pemberian makan anak, serta asupan energi dan protein anak. Akan tetapi, terdapat perbedaan yang 
signifikan antara kelompok kontrol dan perlakuan

Keterangan lebih lanjut, terdapat pada Tabel 3.

pada asupan iron, zinc, dan kalsium $(\mathrm{p}<0,05)$.

Tabel 2. Distribusi frekuensi pengetahuan, sikap, praktik ibu dalam pemberian makan anak, dan asupan

\begin{tabular}{|l|c|c|c|c|}
\hline \multicolumn{2}{|c|}{ zat gizi anak pada awal penelitian } \\
\cline { 2 - 5 } Variabel & N & \%ontrol & N & Perlakuan \\
\hline 1. Pengetahuan ibu & 6 & 30 & 5 & 25 \\
- Kurang (<60\%) & 12 & 60 & 12 & 60 \\
- Cukup (60 - 80\%) & 2 & 10 & 3 & 15 \\
- Baik (>80\%) & 8 & 40 & 9 & 45 \\
\hline 2. Sikap ibu & 12 & 60 & 11 & 55 \\
- Kurang (<60\%) & & & & \\
- Baik (>60\%) &
\end{tabular}

3. Praktik ibu

- Kurang $(\leq 60 \%)$

- Baik $(>60 \%)$

4. Asupan energi

- Defisit $(<70 \%)$

- Kurang (70-80\%)

- Sedang (80-99\%)

- Baik ( $\geq 100 \%$ )

5. Asupan protein

- Defisit $(<70 \%)$

- Kurang (70-80\%)

- Sedang (80-99\%)

- Baik ( $\geq 100 \%$ )

$\begin{array}{llll}11 & 55 & 10 & 50\end{array}$

$9 \quad 45$

50

10

$10 \quad 50$

6. Asupan iron

- Defisit $(<70 \%)$

- Kurang (70-80\%)

- Sedang (80-99\%)

- Baik ( $\geq 100 \%)$

\begin{tabular}{|c|c|c|c|} 
& & & \\
9 & 45 & 13 & 65 \\
4 & 20 & 3 & 15 \\
6 & 30 & 3 & 15 \\
1 & 5 & 1 & 5 \\
\hline
\end{tabular}

. Asupan zinc

- Defisit $(<70 \%)$

- Kurang (70-80\%)

- Sedang (80-99\%)

- Baik ( $\geq 100 \%)$

8. Asupan kalsium

- Defisit (<70\%)

- Kurang (70-80\%)

- Sedang (80-99\%)

- Baik ( $\geq 100 \%)$

$\begin{array}{cc}0 & \\ 1 & \\ 2 & 10 \\ 17 & 85\end{array}$

\begin{tabular}{ccc}
0 & 3 & 15 \\
5 & 1 & 5 \\
10 & 0 & 0 \\
85 & 16 & 80 \\
\hline
\end{tabular}

\begin{tabular}{|c|c|c|c|}
\hline 7 & 35 & 10 & 50 \\
0 & 0 & 0 & 0 \\
2 & 10 & 7 & 35 \\
11 & 55 & 3 & 15 \\
\hline
\end{tabular}

Tabel 3. Perbedaan pengetahuan, sikap, prakti ibu dalam pemberian makan anak, dan asupan zat gizi anak antara kelompok kontrol dan perlakuan pada awal penelitian

\begin{tabular}{|l|c|c|c|}
\hline \multirow{2}{*}{ Variabel } & \multicolumn{2}{|c|}{ Rerata \pm SD } & \multirow{2}{*}{ Signifikansi $(\mathrm{p})$} \\
\cline { 2 - 3 } & Kontrol & Perlakuan & $0,516^{*}$ \\
Pengetahuan & $65,80 \pm 11,42$ & $68,2 \pm 11,714$ & \\
ibu & & & \\
$\mid$ Sikap ibu & $59,80 \pm 5,415$ & $59,00 \pm 4,856$ & $0,626^{*}$ \\
Praktik ibu & $58,67 \pm 12,905$ & $61,67 \pm 9,882$ & $0,414^{*}$ \\
Asupan energi & $71,10 \pm 23,085$ & $60,82 \pm 23,161$ & $0,168^{*}$ \\
Asupan protein & $238,92 \pm 96,441$ & $181,46 \pm 83,038$ & $0,051^{*}$ \\
Asupan iron & $98,85 \pm 45,659$ & $63,54 \pm 39,546$ & $0,012^{* *}$
\end{tabular}




\begin{tabular}{|l|l|l|l|} 
Asupan zinc & $140,60 \pm 66,486$ & $94,72 \pm 45,644$ & $0,015^{*}$ \\
Asupan kalsium & $106,24 \pm 60,301$ & $67,51 \pm 46,867$ & $0,029^{*}$ \\
\hline
\end{tabular}

(*) : Uji Independent t test

Perbedaan pengetahuan, sikap, praktik ibu dalam pemberian makan anak, dan asupan zat gizi anak pada awal dan akhir penelitian dalam kelompok kontrol

Sebagian besar variabel meliputi sikap ibu, praktik ibu dalam pemberian makan anak, asupan energi, protein, iron, zinc, dan kalsium pada kelompok kontrol tidak menunjukkan perbedaan yang signifikan $(\mathrm{p}>0,05)$ antara awal dan akhir penelitian. Namun, ada perbedaan yang signifikan ( $\mathrm{p}<0,05)$ antara pengetahuan ibu pada awal dan akhir penelitian. Keterangan selengkapnya terdapat pada Tabel 4.
Pengetahuan, sikap, praktik ibu dalam pemberian makan anak, dan asupan zat gizi anak pada awal dan akhir penelitian dalam kelompok perlakuan

Semua variabel, yaitu pengetahuan, sikap, praktik ibu dalam pemberian makan anak, asupan energi, protein, iron, zinc, dan kalsium pada kelompok perlakuan memiliki perbedaan yang bermakna ( $\mathrm{p}<0,05)$ pada awal dan akhir penelitian. Hasil tersebut menunjukkan adanya peningkatan skor yang signifikan dari awal hingga akhir penelitian. Selengkapnya, dapat dilihat pada Tabel 4.

Tabel 4. Perbedaan pengetahuan, sikap, prakti ibu dalam pemberian makan anak, dan asupan zat gizi anak pada awal dan akhir penelitian pada kelompok kontrol dan perlakuan

\begin{tabular}{|c|c|c|c|c|c|c|}
\hline \multirow[b]{3}{*}{ Variabel } & \multicolumn{3}{|c|}{ Kontrol } & \multicolumn{3}{|c|}{ Perlakuan } \\
\hline & \multicolumn{2}{|c|}{ Rerata \pm SD } & \multirow[b]{2}{*}{$\begin{array}{l}\text { Signifikan } \\
\quad \text { si (p) }\end{array}$} & \multicolumn{2}{|c|}{ Rerata \pm SD } & \multirow[b]{2}{*}{$\begin{array}{l}\text { Signifikan } \\
\text { si (p) }\end{array}$} \\
\hline & $\begin{array}{c}\text { Awal } \\
\text { penelitian }\end{array}$ & $\begin{array}{c}\text { Akhir } \\
\text { penelitian }\end{array}$ & & $\begin{array}{c}\text { Awal } \\
\text { penelitian }\end{array}$ & $\begin{array}{c}\text { Akhir } \\
\text { penelitian }\end{array}$ & \\
\hline $\begin{array}{l}\text { Pengetahu } \\
\text { an ibu }\end{array}$ & $65,80 \pm 11,42$ & $70,20 \pm 8,847$ & $0,022 *$ & $68,2 \pm 11,714$ & $86,40 \pm 8,35$ & $0,000 *$ \\
\hline Sikap ibu & $59,80 \pm 5,415$ & $60,45 \pm 5,772$ & $0,591 *$ & $59,00 \pm 4,856$ & $66,60 \pm 3,775$ & $0,000 *$ \\
\hline $\begin{array}{l}\text { Praktik } \\
\text { ibu }\end{array}$ & $58,67 \pm 12,905$ & $60,00 \pm 13,157$ & $0,162^{*}$ & $61,67 \pm 9,882$ & $82,00 \pm 7,524$ & $0,000^{*}$ \\
\hline $\begin{array}{l}\text { Asupan } \\
\text { energi }\end{array}$ & $71,10 \pm 23,085$ & $72,29 \pm 16,304$ & $0,637 *$ & $60,82 \pm 23,161$ & $\begin{array}{c}105,84 \pm 20,43 \\
1\end{array}$ & $0,000 *$ \\
\hline $\begin{array}{l}\text { Asupan } \\
\text { protein }\end{array}$ & $\begin{array}{c}238,92 \pm 96,44 \\
1\end{array}$ & $\begin{array}{c}240,95 \pm 61,90 \\
5\end{array}$ & $0,864 *$ & $\begin{array}{c}181,46 \pm 83,03 \\
8\end{array}$ & $\begin{array}{c}322,58 \pm 91,54 \\
7\end{array}$ & $0,000 *$ \\
\hline $\begin{array}{l}\text { Asupan } \\
\text { iron }\end{array}$ & $98,85 \pm 45,659$ & $94,57 \pm 43,801$ & $7 *$ & $63,54 \pm 39,546$ & $118,12 \pm 49,10$ & $0,000 * *$ \\
\hline $\begin{array}{l}\text { Asupan } \\
\text { zinc }\end{array}$ & $\begin{array}{c}140,60 \pm 66,48 \\
6\end{array}$ & $\begin{array}{c}138,02 \pm 43,88 \\
1\end{array}$ & $0,763 *$ & $94,72 \pm 45,644$ & $\begin{array}{c}174,46 \pm 52,34 \\
3\end{array}$ & $0,000 *$ \\
\hline $\begin{array}{l}\text { Asupan } \\
\text { kalsium }\end{array}$ & $\begin{array}{c}106,24 \pm 60,30 \\
1\end{array}$ & $\begin{array}{c}103,36 \pm 63,11 \\
9\end{array}$ & $1,000 *$ & $67,51 \pm 46,867$ & $\begin{array}{c}132,88 \pm 65,83 \\
9\end{array}$ & $0,000 *$ \\
\hline
\end{tabular}

(*) : Uji dependent t test

(**) : Uji Wilcoxon

Perbedaan perubahan rerata pengetahuan, sikap, praktik ibu dalam pemberian makan anak, dan asupan zat gizi anak pada kelompok kontrol dan perlakuan

Hasil membuktikan bahwa perubahan rerata pengetahuan, sikap, praktik, asupan energi, protein, iron, zinc, dan kalsium dari awal hingga akhir penelitian, mempunyai perbedaan yang bermakna $(\mathrm{p}<0,05)$ antara kelompok kontrol dan perlakuan. Peningkatan lebih besar terdapat pada kelompok perlakuan dibandingkan kelompok kontrol. Keterangan lebih lanjut terdapat dalam Tabel 6.

Tabel 6. Perbandingan perubahan rerata pengetahuan, sikap, praktik ibu dalam pemberian makan anak, dan asupan zat gizi anak antara kelompok kontrol dan perlakuan

\begin{tabular}{cccc}
\multirow{2}{*}{ Variabel } & \multicolumn{2}{c}{ Rerata \pm SD } & \multirow{2}{*}{ Signifikansi $(\mathrm{p})$} \\
\cline { 2 - 3 } & Kontrol & Perlakuan & 0,000
\end{tabular}




$\begin{array}{lc}\Delta \text { Sikap } & 0,65 \pm 5,314 \\ \Delta \text { Praktik } & 1,33 \pm 4,104 \\ \Delta \text { Asupan energi } & 1,19 \pm 11,112 \\ \Delta \text { Asupan protein } & 2,04 \pm 52,444 \\ \Delta \text { Asupan } \text { iron } & -4,28 \pm 22,104 \\ \Delta \text { Asupan zinc } & -2,57 \pm 37,623 \\ \Delta \text { Asupan kalsium } & -2,87 \pm 27,56\end{array}$

\section{PEMBAHASAN}

Hasil penelitian menunjukkan sebagian besar anak stunting usia 1-2 tahun di Semarang Timur adalah perempuan. Hasil ini berbeda dengan penelitian sebelumnya yang menunjukkan bahwa laki-laki lebih berisiko mengalami stunting daripada perempuan. Namun, hasil tersebut bervariasi dalam berbagai penelitian lainnya. ${ }^{19}$ Dibuktikan dengan penelitian lain yang memperoleh hasil bahwa jenis kelamin tidak berhubungan secara signifikan dengan stunting. ${ }^{20}$

Riwayat memberikan ASI yang tidak eksklusif terjadi pada sebagian besar subjek. Hal ini ditunjukkan dengan pemberian makanan selain ASI, diberikan pertama kali oleh ibu sebagian besar pada saat anak berusia 4 bulan, bahkan ada beberapa ibu yang tidak memberikan ASI sama sekali dengan alasan ASI tidak keluar, bayi tidak mau minum ASI, dan ASI yang keluar hanya sedikit. Hasil ini mendukung penelitian sebelumnya yang membuktikan bahwa pemberian ASI eksklusif mempunyai hubungan yang signifikan terhadap status gizi terutama untuk zskor TB/U. ${ }^{7}$ Makanan pertama selain ASI yang diberikan pada anak, antara lain pisang lumat, bubur, biskuit, dan susu formula.

Subjek sebagian besar tidak bekerja sehingga pendapatan keluarga hanya berasal dari suami. Pendapatan keluarga per bulan yang hanya berasal dari suami rata-rata < UMK Semarang, yaitu sebesar Rp 1.169.600,00. Hasil tersebut sama dengan penelitian sebelumnya yang menyatakan bahwa stunting lebih banyak terjadi pada keluarga dengan pendapatan rata-rata per bulan yang rendah. ${ }^{20}$ Pendapatan keluarga dapat ditingkatkan dengan ibu yang turut bekerja sehingga dapat berpengaruh terhadap peningkatan ketahanan pangan, kualitas diet anak, dan pelayanan kesehatan. ${ }^{21}$

Tingkat pendidikan ibu sebagian besar tinggi, yaitu tamatan SMA. Pendidikan yang tinggi lebih memudahkan ibu dalam menerima informasi gizi dan kesehatan. ${ }^{22}$ Hal ini ditunjukkan responden pada awal penelitian memiliki pengetahuan gizi yang cukup, dan sikap yang baik. Namun, dalam praktik pemberian makan anak

$\begin{array}{cc}7,60 \pm 3,952 & 0,000 \\ 20,33 \pm 6,297 & 0,000 \\ 45,02 \pm 13,296 & 0,000 \\ 141,12 \pm 64,15 & 0,000 \\ 54,59 \pm 35,211 & 0,000 \\ 79,74 \pm 35,462 & 0,000 \\ 65,37 \pm 40,985 & 0,000\end{array}$

masih kurang karena sikap belum tentu terwujud dalam praktik. Terwujudnya praktik diperlukan faktor lain, yaitu fasilitas. ${ }^{23}$ Dalam hal ini berupa konseling gizi dari tenaga kesehatan yang berfungsi untuk mencapai perubahan perilaku. ${ }^{12}$ Pada penelitian ini, responden sudah mempunyai kesiapan untuk melakukan praktik pemberian makan yang baik, tetapi dalam pelaksanaannya responden mengalami permasalahan dalam pemilihan bahan makanan maupun cara menangani anak yang mempunyai kesulitan makan.

Pada awal penelitian, pengetahuan, sikap, dan praktik ibu dalam pemberian makan anak, serta asupan energi dan protein anak tidak berbeda pada kelompok kontrol maupun perlakuan. Akan tetapi, asupan iron, zinc, dan kalsium pada anak berbeda secara signifikan pada kedua kelompok, yaitu berdasarkan hasil food recall 3 x 24 jam, kelompok kontrol lebih tinggi dibanding kelompok perlakuan karena pada kelompok kontrol konsumsi bahan makanan, terutama susu formula lebih tinggi. Anak- anak pada kelompok kontrol rata-rata mengonsumsi sebanyak 68 gram tepung susu per hari, sedangkan pada kelompok perlakuan sebanyak 31 gram tepung susu per hari. Anak-anak pada kelompok kontrol lebih tinggi mengonsumsi susu formula karena 55\% anak pada kelompok kontrol diberikan susu formula sebagai MP-ASI pertama, sedangkan pada kelompok perlakuan hanya sebesar $35 \%$, sehingga keterpaparan susu formula lebih dini pada kelompok kontrol. Perbedaan asupan iron, zinc, dan kalsium pada awal penelitian ini dapat menyebabkan hasil menjadi bias.

Selain iron, zinc, dan kalsium, susu formula juga mengandung tinggi energi. Namun, asupan energi anak pada kelompok kontrol dan perlakuan tidak berbeda karena pada kelompok kontrol asupan susu formula yang tinggi menyebabkan asupan makanan anak rendah. Sedangkan kelompok perlakuan, asupan susu formula yang rendah menyebabkan asupan makanan anak menjadi lebih tinggi.

Pada kelompok kontrol, menunjukkan terdapat perbedaan yang signifikan antara pengetahuan ibu pada awal dan akhir penelitian. 
Hal tersebut karena terdapat faktor-faktor luar yang tidak dapat dikendalikan oleh peneliti. Setelah pengukuran pengetahuan ibu pada awal penelitian, terdapat beberapa peneliti lain yang melakukan penelitian mengenai stunting pada beberapa subjek yang sama, sehingga kemungkinan ada beberapa informasi gizi pada penelitian ini yang hampir sama dengan penelitian lain. Oleh karena itu, skor pengetahuan ibu pada akhir penelitian kemungkinan mengalami bias. Selain itu, responden juga memperoleh informasi gizi dari kader posyandu setiap bulannya melalui penyuluhan pada meja kelima posyandu.

Pengetahuan ibu yang meningkat pada kelompok kontrol, tidak menyebabkan sikap, dan praktik ibu juga mengalami peningkatan secara signifikan antara awal dan akhir penelitian. Hal tersebut dikarenakan subjek tidak mendapat konseling gizi yang merupakan kegiatan komunikasi dua arah yang dapat menanamkan dan meningkatkan pengertian, sikap, dan perilaku sehingga membantu subjek mengenali dan mengatasi masalah gizi. ${ }^{12}$ Dalam hal ini, subjek hanya mendapatkan informasi gizi dari penyuluhan gizi yang mengarah pada komunikasi satu arah, sehingga sikap dan perilaku menunjukkan tidak ada peningkatan. Oleh karena itu, asupan zat gizi anak juga tidak menunjukkan adanya peningkatan yang signifikan $(\mathrm{p}>0,05)$.

Pada kelompok perlakuan, semua variabel meliputi pengetahuan, sikap, dan praktik ibu dalam pemberian makan anak, serta asupan zat gizi anak meningkat secara signifikan $(\mathrm{p}<0,05)$ pada awal dan akhir penelitian. Hasil tersebut menguatkan penelitian yang menyebutkan bahwa konseling gizi sangat berperan penting dalam memperbaiki kepatuhan $\operatorname{diet}^{24}$ karena konseling gizi adalah suatu pendekatan personal yang digunakan untuk menolong individu memperoleh pengertian yang lebih baik mengenai permasalahan gizi yang dihadapi dan memotivasi menuju perubahan perilaku. Selanjutnya individu mampu mengambil langkah-langkah dalam mengatasi permasalahan gizi tersebut, termasuk perubahan praktik pemberian makan. ${ }^{12}$ Meningkatnya perilaku ibu mengenai pemberian makan pada anak, menjadikan asupan zat gizi anak juga meningkat. Hal tersebut menunjukkan bahwa konseling gizi yang dilakukan 1 kali tiap minggu terbukti cukup efektif dalam perubahan perilaku pemberian makan.

Perubahan rerata pengetahuan, sikap, dan praktik ibu dalam pemberian makan anak, dari awal hingga akhir penelitian, mempunyai perbedaan yang bermakna $(\mathrm{p}<0,05)$ pada kelompok perlakuan dibandingkan kelompok kontrol. Hasil ini sama dengan penelitian yang dilakukan oleh Noviati (2006) bahwa konseling gizi yang dilakukan di posyandu terbukti dapat meningkatkan pengetahuan, sikap, dan praktik ibu secara signifikan pada kelompok perlakuan dibandingkan kelompok kontrol. ${ }^{13}$ Peningkatan perilaku pemberian makan, menyebabkan asupan energi, protein, iron, zinc, dan kalsium pada anak juga meningkat dengan signifikan $(\mathrm{p}<0,05)$ pada kelompok perlakuan dibandingkan kelompok kontrol.

\section{KESIMPULAN}

Terdapat perbedaan pengetahuan yang signifikan antara sebelum dan setelah konseling gizi pada kelompok kontrol, tetapi tidak terdapat perbedaan yang signifikan pada sikap, praktik ibu, asupan energi, protein, iron, zinc, dan kalsium. Kelompok perlakuan menunjukkan adanya perbedaan yang signifikan pada pengetahuan, sikap, praktik ibu, dan asupan zat gizi anak meliputi energi, protein, iron, zinc, kalsium. Terdapat perbedaan perubahan pengetahuan, sikap, dan praktik ibu, serta asupan zat gizi anak (energi, protein, iron, zinc, kalsium) antara kelompok perlakuan dan kelompok kontrol.

\section{DAFTAR PUSTAKA}

1. Caballero B, Maqbool A. International Nutrition. In : Walker WA, Watkins JB, Duggan C. Nutrition in Pediatrics. Third Edition. London : BC Decker Inc; 2003. p 195-198.

2. Kementerian Kesehatan RI Direktorat Jenderal Bina Gizi dan Kesehatan Ibu dan Anak. Keputusan Menteri Kesehatan Republik Indonesia Nomor : 1995/MENKES/SK/XII/2010 Tentang Standar Antropometri Penilaian Status Gizi Anak. Jakarta; 2011.

3. Badan Penelitian dan Pengembangan Kesehatan Departemen Kesehatan RI. Laporan hasil Riset Kesehatan Dasar 2010. Jakarta; 2010. p iii, 23, 26.

4. Puspitasari FD, Sudargo T, Gamayanti IL. Hubungan Antara Status Gizi dan Faktor Sosiodemografi dengan Kemampuan Kognitif Anak Sekolah Dasar di Daerah Endemis GAKI. Gizi Indonesia 2011; 34(1):52-60

5. Astari LD, Nasoetion A, Dwiriani CM. Hubungan Konsumsi ASI Dan MP-ASI Serta Kejadian Stunting Anak Usia 6-12 Bulan di Kabupaten Bogor. Media Gizi dan Keluarga Juli 2006; 30 (1) 15-23.

6. Roosita K, Sunarti E, Herawati T. Nutrient Intake and Stunting Prevalence among Tea Plantation Workers' Children in Indonesia. Journal of 
Developments in Sustainable Agriculture 2010; 5: 131-135. [accessed Desember 10, 2012]. Available from: URL: http:/www.jstage.jst.go.jp/article/jdsa/5/1/5_1_131 /_pdf.

7. Susilowati, Kusharisupeni, Fikawati S, Achmad K. Breast-feeding duration and children's nutritional status at age 12-24 months. Paediatrica Indonesiana January 2010; 50: 56-61.

8. Imdad A, Yakoob MY, Bhutta ZA. Impact of maternal education about complementary feeding and provision of complementary foods on child growth in developing countries. BMC Public Health 2011; 11(Suppl 3):S25. [accessed December 10, 2012]. Available from: URL: http://www.biomedcentral.com/14712458/11/S3/S25.

9. Rah JH, Akhter N, Semba RD, de Pee S, Bloem MW, Campbell AA, et al. Low dietary diversity is a predictor of child stunting in rural Bangladesh. European Journal of Clinical Nutrition 2010; 64: 1393-1398. [accessed December 13, 2012]. Available from: URL: www.nature.com/ejcn.

10. Astari LD, Nasoetion A, Dwiriani CM. Hubungan Karakteristik Keluarga, Pola Pengasuhan dan Kejadian Stunting Anak Usia 6-12 Bulan. Media Gizi dan Keluarga 2005; 29 (2): 40-46.

11. Jesmin A, Yamamoto SS, Malik AA, Haque MA. Prevalence and Determinants of Chronic Malnutrition among Preschool Children: A Crosssectional Study in Dhaka City, Bangladesh. J Health Popul Nutr October 2011; 29(5):494-499. [accessed December 10, 2012]. Available from: URL:

http://www.ncbi.nlm.nih.gov/pmc/articles/PMC32 25111/

12. PERSAGI. Penuntun Konseling Gizi. Jakarta : PT. Abadi; 2011. Hlm 12,25-47.

13. Noviati, Susanto JC, Selina H, Mexitalia M. The influence of intensive nutritional counseling in Posyandu towards the growth 4-18 month old children. Paediatrica Indonesiana 2006; 46: 57-63.

14. Ramli, Agho KE, Inder KJ, Bowe SJ, Jacobs J, Dibley MJ. Prevalence and risk factors for stunting and severe stunting among under-fives in North Maluku province of Indonesia. BMC Pediatrics 2009; 9:64. [accessed December 10, 2012]. Available from: URL: http://www.biomedcentral.com/1471-2431/9/64.

15. World Health Organization (WHO). Infant and Young Child Feeding. WHO; 2009. p 4.

16. Badan Pusat Statistik. Istilah Statistik. Jakarta; 2013. [accessed Novenber 10, 2013]. Available from: URL: http://www.bps.go.id/menutab.php?tab=6\&ist=1\& $\operatorname{var}=\mathrm{P}$.

17. Azwar S. Sikap Manusia Teori dan Pengukurannya. Edisi kedua. Yogyakarta : Pustaka Pelajar; 2011. Hlm 154-157.
18. Supariasa IDN, Bachyar B, Ibnu F. Penilaian Status Gizi. Jakarta: EGC; 2002. hlm 114.

19. Wamani H, Astrom AN, Peterson S, Tumwine JK, Tylleskar T. Boys are more stunted than girls in Sub-Saharan Africa: a meta-analysis of 16 demographic and health surveys. BMC Pediatrics 2007, 7: 17. . [accessed December 10, 2012]. Available from: URL: http://www.biomedcentral.com/1471-2431/7/17.

20. Mushtaq MU, Gull S, Khurshid U, Shahid U, Shad MA, Siddiqui AM. Prevalence and sociodemographic correlates of stunting and thinness among Pakistani primary school children. BMC Public Health 2011; 11:790. [accessed December 27, 2012]. Available from: URL: http://www.biomedcentral.com/1471-2458/11/790.

21. Willey BA, Cameron N, Norris SA, Pettifor JM, Griffiths PL. Socio-economic predictors of stunting in preschool children a population-based study from Johannesburg and Soweto. South African Medical Journal 2009; 99:450-456. [accessed December 27, 2012]. Available from: URL: http://hdl.handle.net/2134/6424.

22. Rahmawati D. Status gizi dan perkembangan anak usia dini di Taman Pendidikan Karakter Sutera Alam, Desa Sukamantri. Bogor [Skripsi]. Bogor: Fakultas Pertanian. Institut Pertanian Bogor. 2006

23. Notoatmodjo S. Ilmu Perilaku Kesehatan. Jakarta : PT Rineka Cipta; 2010. hlm 20, 26-33, 83, 88-91.

24. Snetselaar LG. Nutrition Counseling Skill for the Nutrition Care Process. Fourth Edition. USA : Jones and Bartlett Publishers; 2009. p 3-4, 22 